\title{
THEORETICAL AND APPLIED ASPECTS OF ANALYSIS OF INTEGRATED REPORTING OF AGRICULTURAL CORPORATIONS: HUMAN CAPITAL
}

\author{
Ruslan Kostyrko ${ }^{1}$, Denys Prozorov ${ }^{2}$
}

\begin{abstract}
The purpose of the paper is to improve scientific and applied aspects of analysis of integrated reporting of agricultural corporations on the example of human capital indicators. Methodology. Theoretical aspects of the study are based on the international standards of the Global Reporting Initiative and AccountAbility. Applied aspects are the generalization and critical evaluation of the form, content, quantitative and qualitative indicators of integrated reporting of agricultural corporations. The results of the paper are to define nonfinancial reporting as an integrated format of information on natural, industrial, financial, human, intellectual, social, institutional capital of enterprises. It is shown that the development of the system of formation and presentation of integrated reporting is influenced by two trends that are somewhat mutually exclusive: firstly, supranational regulation by GRI and AA1000 standards; secondly, the voluntary nature and predominance of content over form, which cause significant differences in formats and the difficulty of conducting a comparative analysis of reporting enterprises. It is proved that integrated reporting is a comprehensive set of quantitative and qualitative indicators, which are divided into general, common to all enterprises of the national economy, and specific, inherent in certain types of economic activity. For agricultural corporations, the latter are: protection of agricultural lands, animal well-being, state and directions of development of organic production, etc. The components of integrated reporting of four agricultural corporations of Ukraine are summarized. Their similarity is determined by the substantive characteristics associated with the disclosure of information about the impact of the enterprise on the environment, social and economic impact, corporate governance, animal well-being. The differences are related to the form of presentation of information, the number of sections of integrated reporting. The conceptual basis of human capital management and features of program in separate researched agrarian corporations are generalized. The analysis of human capital as an object of integrated reporting of agricultural corporations on the indicators of the total number of staff, its permanent and seasonal part, gender composition, categories of employees, age, and duration of training has been performed. Practical implications are the development of recommendations aimed at eliminating the shortcomings of the disclosure of information about human capital associated with the prevalence of quantitative indicators over qualitative ones. It is proposed to use indicators of labor productivity, average wages compared to the industry level, as well as motivational mechanisms for staff in the form of corporate health insurance. Value/originality. The necessity of data integration is substantiated not only at the level of the non-financial report, but also at the level of separate sections, which is advisable to be represented by separate types of capital. On the example of the section "Human capital" it is recommended to highlight the units related to its economic, social, cultural, intellectual development, etc. in its composition.
\end{abstract}

Key words: integrated reporting, agricultural corporations, analysis, theoretical and applied aspects, European integration, international standards, human capital.

JEL Classification: D24, M41, 013

\footnotetext{
Corresponding author

${ }^{1}$ Banking University, Ukraine.

E-mail: ruslankostyrko@gmail.com

ORCID: https://orcid.org/0000-0001-9247-3363

${ }^{2}$ Banking University, Ukraine.

E-mail: den.proz.ua@gmail.com

ORCID: https://orcid.org/0000-0002-2459-2499
} 


\section{Introduction}

In the modern conditions of global challenges not only of economic, but also of social, ecological, human-caused, and epidemiological character, the role of a paradigm of sustainable development grows. The accession of business entities to the UN Global Initiative requires the formation and disclosure of non-financial reporting. Increased attention to integrated reporting emerged in 2013. Nowadays, a variety of methods, mostly qualitative ones, are used to research this concept (Romolini, Fissi, Gori, 2017). The relevance of the issue is growing in the current situation, as the implementation of IFRS and integrated reporting will contribute to Ukraine's European integration. Unfortunately, in Ukraine there is a limited list of companies that report on sustainable development standards, publish non-financial statements, provide eco-social indicators in public financial reporting, report in GRI format (Patrikats, Patsera, 2013). First of all, these are international companies, large corporations, vertically integrated structures of the fuel and energy complex and the agricultural sector of the economy. Compilation and publication of reports in the field of sustainable development allows them to receive the following benefits: brand support, stakeholder trust, business reputation, building customer and employee loyalty, reducing costs and increasing profits, (Vasylishyn, 2020), increasing the company's ability to generate cash flows in the future, improving investment attractiveness, ensuring transparency of information on development strategies, strengthening the responsibility of business entities, taking into account the interests of employees and aligning them with economic goals of the companies, strengthening environmental safety, increasing social and legal protection of workers (Sobchenko, Krukovska, 2015).

The reasons for the development of integrated reporting are related to the limited information capacity of traditional financial reporting, which does not allow to fully track the migration of cost, value, etc. Supranational regulation and standardization play an important role in the formation of integrated reporting. However, the voluntary nature of integrated reporting and the lack of strict unification determines the purpose of the article, which is to improve the scientific and applied aspects of the analysis of its indicators on the example of human capital of agricultural corporations of Ukraine.

\section{Supranational regulation and standardization of integrated reporting}

In 2010, the International Integrated Reporting Council (IIRC) was established, which launched a pilot program to define the norms for the development of integrated reporting principles (Havlová, 2015). The IIRC has recognized the concept of integrated reporting, which combines information on finance, public oversight, the environment and social aspects into a single integrated format (Kostyrko, 2014). The development of international standards for nonfinancial reporting is focused on the unification of approaches to solving problems of climate change, non-renewable resources, environmental pollution both globally and nationally (Yefymenko, 2014).

Compilation of integrated reporting is voluntary and takes place according to the standards of GRI (Global Reporting Initiative) and AA1000 (AccountAbility). The quality of integrated reporting is verified by an independent audit in accordance with International Standard on Assurance Engagements (ISAE) 3000 Revised, Assurance Engagements others than Audits or Reviews of Historical Information. The integrated report provides an understanding of the company's strategic goal and how it relates to the company's ability to reproduce and maintain value over the long term with the resources and relationships on which its sustainable development depends.

Integrated reporting is a product of holistic and integrated thinking in business and requires a preliminary and fundamental integrated rationale, reflecting the way in which the company achieves added value, encouraging a holistic assessment of business drivers (Stovpova, 2019). Its purpose is to support the adoption of long-term decisions, strengthening the practice of transparent reporting and fostering a culture of governance.

\section{Components of integrated reporting of agricultural corporations}

Integrated reporting is a comprehensive set of quantitative and qualitative indicators that characterize the commercial, social and environmental components in the activities of economic agents, as well as value growth in the short, medium and long term. An important object of non-financial reporting is the capital used: natural, industrial, financial, human, intellectual, social, institutional. 
Components of integrated reporting can be divided into general, common to all enterprises of the national economy, and specific, inherent in certain types of economic activity. For agricultural corporations, the latter are: protection of agricultural land, animal well-being, the state and directions of development of organic production, compliance with legal requirements for its accounting (Ishchenko, 2019).

Table 1 shows the components of integrated reporting of agricultural corporations of Ukraine.

The number of sections of the integrated report ranges from three in IMC to ten in MHP SE, Kernel Holding S.A. has five sections, ASTARTA Holding N.V. has four sections. Information on human capital is reflected in various sections of integrated reporting: Kernel Holding S.A. - in "Social impact", ASTARTA Holding N.V. - "Social and inclusion",
IMC - "Personnel", MHP SE - "People" (with a separate section "Employee health and safety").

Despite the different structuring and emphasis on individual accents, the global goal of agricultural corporations in terms of sustainable development and social responsibility is the development of society through voluntary contributions to the social, economic and environmental spheres related to the activities and strategic goals of business structures.

Common areas of activity are:

- preservation of the environment, rational use of natural resources, protection of lands and a healthy environment;

- responsible performance of employer's functions, promotion of professional and personal development of staff, use of a competitive system of rewards;

Table 1

\section{Components of integrated reporting of agricultural corporations of Ukraine}

\begin{tabular}{|c|c|c|}
\hline Name of the corporation & Components of integrated reporting & $\begin{array}{l}\text { Components of integrated reporting } \\
\text { in terms of human capital }\end{array}$ \\
\hline Kernel Holding S.A. & $\begin{array}{l}\text { 1. Kernel today } \\
\text { 2. Environmental impact } \\
\text { 3. Social impact } \\
\text { 4. Economic impact } \\
\text { 5. Corporate governance }\end{array}$ & $\begin{array}{l}\text { 3. Social impact } \\
\text { 3.1. Employment } \\
\text { 3.2. Training and education activities } \\
\text { 3.3. Local communities } \\
\text { 3.4. Occupational health \& safety }\end{array}$ \\
\hline ASTARTA Holding N.V. & $\begin{array}{l}\text { 1. Astarta } \\
\text { 2. Environmental } \\
\text { 3. Social and inclusion } \\
\text { 4. Governance }\end{array}$ & $\begin{array}{l}\text { 3. Social and inclusion } \\
\text { 3.1. Cooperation with Local Communities } \\
\text { 3.2. Human Capital } \\
\text { 3.3. Human Rights } \\
\text { 3.4. Occupational Health and Safety } \\
\text { 3.5. Managing COVID-19 Related Risks } \\
\text { 3.6. Responsible Procurement }\end{array}$ \\
\hline IMC & $\begin{array}{l}\text { 1. Personnel } \\
\text { 2. Health, safety, environment } \\
\text { 3. Social program "IMC. Aid to people" }\end{array}$ & $\begin{array}{l}\text { 1. Personnel } \\
\text { 1.1. IMC Team } \\
\text { 1.2. Motivation and Involvement } \\
\text { 1.2.1. Financial incentives } \\
\text { 1.2.2. Non-financial incentives } \\
\text { 1.2.3. Corporate events } \\
\text { 1.2.4. Sport corporate events } \\
\text { 1.3. Education }\end{array}$ \\
\hline MHP SE & $\begin{array}{l}\text { 1. Our approach } \\
\text { 2. Governance } \\
\text { 3. Environment and climate change } \\
\text { 4. Employee health and safety } \\
\text { 5. Product quality and safety } \\
\text { 6. Animal welfare } \\
\text { 7. People } \\
\text { 8. Stakeholder engagement } \\
\text { 9. Business conduct } \\
\text { 10. About this Report } \\
\end{array}$ & $\begin{array}{l}\text { 7. People } \\
\text { 7.1. Achievements, policy and system highlights } \\
\text { 7.2. People case studies } \\
\text { 7.3. People data (Ukraine) } \\
\text { 7.4. Training and education } \\
\text { 7.5. People data (EOS) and plans for } 2020\end{array}$ \\
\hline
\end{tabular}

Source: ASTARTA, 2021; IMC, 2019; Kernel, 2021; MHP, 2020 
- support of local communities, improvement and development of settlements in rural areas, infrastructure development, repair of roads, water mains / wells, public buildings;

- social support for employees and the general population (health care, child care, charity, culture and sports, etc.);

- welfare of animals - their freedom (from hunger and thirst; from injury and discomfort; from pain, injury or disease; from fear and stress; freedom of natural behavior), providing professional qualified veterinary care, provision and implementation of methods and processes of humane breeding, transportation and slaughter in accordance with industry best practices; refusal to use growth hormones, a policy of minimal use of antibiotics.

Human capital management in agricultural corporations integrates business and social components and needs more detailed development.

\section{Conceptual and program principles of human capital management in agricultural corporations}

The main element of human capital are employees of the enterprise, their culture and skills, moral and material motivation, social security, training and development, honesty and trust, teamwork. Integrated reporting can be implemented through legitimization measures taken by corporate social responsibility managers. Their professional competencies are the organization of the enterprise activity, ensuring the efficient use of available resources, internal interaction and external communications between different groups of stakeholders through network structures (Argento, Culasso, Truant, 2019).

The personnel policy of agricultural corporations is approved, reviewed by the board of directors and communicated to all stakeholders. It usually sets out the structure of personnel management of the company, determines the principles of selection, training and development, remuneration of workers, communications, representation, confidentiality, working hours, leave, complaints and labor disputes.

The main principles of human capital management are: attention to each employee, support for the fullest realization of his or her potential; transparency and protection of confidentiality of each employee; ensuring equal opportunities and non-discrimination on the basis of personal characteristics that are not related to the results of work activities or performance; prohibition of the use of child labor, forced labor and slavery; support for freedom of association.

Let us consider in more detail the conceptual and programmatic principles of human capital management in some of the studied agricultural corporations.

ASTARTA Holding N.V. embodies its mission based on the values of impeccable business reputation, corporate social responsibility, respect for human dignity and synergetic partnership. The company is guided by the Personnel and Social Policy, aimed at ensuring equal opportunities and supporting its long-term strategy. Gender diversity is important, as are age, ethnicity, and so on. Employees are hired and promoted according to their qualifications and results. In accordance with its Social Policy, ASTARTA Holding N.V. provides financial assistance to its employees for medical treatment, childbirth and marriage, and supports participants in Operation Allied Forces. The company has created an internal training system using best international and Ukrainian practices. Mentoring programs (seniors share experiences with juniors, while juniors help seniors work with digital technologies), personnel reserve, training and integration activities, and employee participation in strategic projects play an important role in team formation and maintenance.

The development of MHP SE's corporate culture is aimed at increasing people's wellbeing, forming values and competency models, improving work efficiency and productivity of employees and the organization as a whole, introducing new training formats, moving to more uniform, flexible and adaptive personnel management models, characterized by increased interaction. The main programs of MHP SE human capital increase are: MHP Leaders HUB program; internal hackathon; development of internal and external communications on the basis of a cooperation agreement with a specialized online media "Latifundist"; mentoring and training for students of agricultural faculties (Agrokebet program); attracting talents from the community to encourage innovation and creativity within the Accelerator 2.0 program; support for innovations in children's education in cooperation with the non-governmental organization "Osvitoria", awarding national prizes in the field of teaching and funding to support innovation. 
An important promising area of development of agricultural corporations is the launch of corporate medical programs.

\section{Analysis of human capital as an object of integrated reporting of agricultural corporations}

Integrated reporting of agricultural corporations contains information on the total number and structure of agricultural corporations employees, their distribution by gender, job category of agricultural corporations, age distribution of agricultural corporations employees.

By the number of employees agrarian corporations in 2017-2019 can be placed in this way (Table 2): 1st place - MHP SE (more than 27.5 thousand people, slight increase), 2nd place - Kernel Holding S.A. (reduction from 16.1 thousand people to 13.4 thousand people), 3rd place - ASTARTA Holding N.V. (reduction from 9.2 thousand people to 5.5 thousand people), 4th place - IMC (reduction from 2.4 thousand people to 2.3 thousand people during 2017-2018).

According to gender, women dominate at MHP and IMC (Table 3), the male/female ratio is 39:61 (in 2019) and 29:71 (in 2018), respectively.

Men dominate in ASTARTA Holding N.V. and Kernel Holding S.A., the ratio of male/ female in 2019 was 63:37 and 74:26, respectively. The ratio of women's basic wages to men's is subject to control. At ASTARTA Holding N.V. in 2019 it is 90:100 compared to 80:100 in 2018. This difference is due to the fact that men are involved in more intensive and physical types of work, which provides higher wages.

In all agricultural corporations the main job category is workers (Table 4 ).

Table 2

Total number and structure of agricultural corporations employees

\begin{tabular}{|c|c|c|c|c|c|c|c|c|c|c|c|}
\hline \multirow[t]{2}{*}{ Year } & \multirow{2}{*}{$\begin{array}{c}\text { Total } \\
\text { number of } \\
\text { employees }\end{array}$} & \multicolumn{2}{|c|}{ Staff members } & \multicolumn{2}{|c|}{$\begin{array}{c}\text { Permanent } \\
\text { employment } \\
\text { agreement }\end{array}$} & \multicolumn{2}{|c|}{$\begin{array}{c}\text { Interim } \\
\text { employment } \\
\text { agreement }\end{array}$} & \multicolumn{2}{|c|}{ Full employment } & \multicolumn{2}{|c|}{$\begin{array}{c}\text { Part-time } \\
\text { employment }\end{array}$} \\
\hline & & $\mathrm{M}$ & $\mathrm{F}$ & $\mathrm{M}$ & $\mathrm{F}$ & $\mathrm{M}$ & $\mathrm{F}$ & $\mathrm{M}$ & $\mathrm{F}$ & $\mathrm{M}$ & $\mathrm{F}$ \\
\hline & \multicolumn{11}{|c|}{ MHPSE, persons } \\
\hline 2019 & 27731 & 10900 & 16831 & 10529 & 16563 & 371 & 268 & 10470 & 16507 & 425 & 329 \\
\hline 2018 & 28703 & 11184 & 17519 & 10830 & 17200 & 354 & 319 & 10998 & 17361 & 186 & 158 \\
\hline \multirow[t]{2}{*}{2017} & 27589 & 10893 & 16696 & 10202 & 16835 & 313 & 239 & 10195 & 16736 & 351 & 307 \\
\hline & \multicolumn{11}{|c|}{ ASTARTA Holding N.V., persons } \\
\hline 2019 & 5470 & 3458 & 2012 & 4566 & 904 & - & - & - & - & & \\
\hline 2018 & 7041 & 4669 & 2372 & 6064 & 977 & - & - & - & - & & \\
\hline 2017 & 9203 & 6167 & 3036 & 7989 & 1214 & - & - & - & - & & \\
\hline & \multicolumn{11}{|c|}{ IMC, persons } \\
\hline 2018 & 2309 & 1601 & 708 & - & - & - & - & - & - & & \\
\hline 2017 & 2412 & 1714 & 698 & - & - & - & - & - & - & & \\
\hline & \multicolumn{11}{|c|}{ Kernel Holding S.A., thsd persons } \\
\hline 2019 & 13.4 & 9.9 & 3.5 & - & - & - & - & - & - & & \\
\hline 2018 & 15.1 & 11.1 & 4 & - & - & - & - & - & - & & \\
\hline 2017 & 16.1 & 11.3 & 4.8 & - & - & - & - & - & - & & \\
\hline
\end{tabular}

Source: ASTARTA, 2021; IMC, 2019; Kernel, 2021; MHP, 2020

Table 3

Employees of agricultural corporations by gender

\begin{tabular}{|c|c|c|c|c|c|c|}
\hline Gender & 2019 & 2018 & 2017 & 2019 & 2018 & 2017 \\
\hline Male & 39 & 39 & 40 & - & 29 & 31 \\
\hline Female & 61 & 61 & 60 & - & \multicolumn{3}{|c|}{ Kernel Holding S.A. } \\
\hline & \multicolumn{2}{|c|}{ MHP SE } & \multicolumn{3}{|c|}{7} \\
\hline Male & 63 & 66 & 67 & 74 & 74 & 70 \\
\hline Female & 37 & 34 & 33 & 26 & 26 & 30 \\
\hline
\end{tabular}

Source: ASTARTA, 2021; IMC, 2019; Kernel, 2021; MHP, 2020 
Table 4

Job category of agricultural corporations

\begin{tabular}{|c|c|c|c|c|c|c|}
\hline \multirow{2}{*}{ Year } & \multicolumn{2}{|c|}{ Managers } & \multicolumn{2}{|c|}{ Professionals } & \multicolumn{2}{|c|}{ Workers } \\
\hline & Number & $\%$ & Number & $\%$ & Number & $\%$ \\
\hline & \multicolumn{6}{|c|}{ MHP SE, persons } \\
\hline 2019 & 2505 & 9 & 4323 & 15 & 21875 & 76 \\
\hline 2018 & 2401 & 8 & 5038 & 18 & 20349 & 74 \\
\hline \multirow[t]{2}{*}{2017} & 1578 & 6 & 4921 & 18 & 21232 & 76 \\
\hline & \multicolumn{6}{|c|}{ ASTARTA Holding N.V., persons } \\
\hline 2019 & 790 & 14 & 1444 & 27 & 3236 & 59 \\
\hline 2018 & 952 & 14 & 1782 & 25 & 4307 & 61 \\
\hline \multirow[t]{2}{*}{2017} & 975 & 11 & 1968 & 21 & 6260 & 68 \\
\hline & \multicolumn{6}{|c|}{ Kernel Holding S.A., thsd persons } \\
\hline 2019 & 0,9 & 7 & 3,7 & 28 & 8,8 & 66 \\
\hline 2018 & 1 & 7 & 4 & 26 & 10,2 & 67 \\
\hline 2017 & 1.2 & 7 & 3.8 & 24 & 11.1 & 69 \\
\hline
\end{tabular}

Source: ASTARTA, 2021; Kernel, 2021; MHP, 2020

The highest is its share in MHP (76\%), the lowest - in ASTARTA Holding N.V. (reduction during 2017-2019 from 68\% to 59\%). By predominant share ASTARTA Holding N.V. and Kernel Holding S.A. have similar job category "professionals", which increased respectively - from $21 \%$ to $27 \%$, from $24 \%$ to $28 \%$. Kernel Holding S.A. has the lowest share of managers (7\%), ASTARTA Holding N.V. has twice as much (growth from 11\% to 14\%).
In all agricultural corporations, the main age group of employees is 30-50 years (Table 5). In 2019, it ranged from 55\% (ASTARTA Holding N.V.) to 59\% (MHP SE).

MHP SE has the largest share of young people (employees aged under 30), although it decreased slightly - from $22 \%$ to $21 \%$. ASTARTA Holding N.V. (30\%) has the largest share of older generations (employees aged over 50).

Table 5

Age distribution of agricultural corporations employees

\begin{tabular}{|c|c|c|c|c|c|c|}
\hline \multirow{3}{*}{ Year } & \multicolumn{6}{|c|}{ Employees aged } \\
\hline & \multicolumn{2}{|c|}{ under 30} & \multicolumn{2}{|c|}{ between 30 and 50} & \multicolumn{2}{|c|}{ over 50} \\
\hline & Number & $\%$ & Number & $\%$ & Number & $\%$ \\
\hline & \multicolumn{6}{|c|}{ MHP SE, persons } \\
\hline 2019 & 5808 & 21 & 16323 & 59 & 5600 & 20 \\
\hline 2018 & 7037 & 25 & 15278 & 53 & 6388 & 22 \\
\hline \multirow[t]{2}{*}{2017} & 6109 & 22 & 15057 & 55 & 6423 & 23 \\
\hline & \multicolumn{6}{|c|}{ Astarta Holding N.V., persons } \\
\hline 2019 & 824 & 15 & 3025 & 55 & 1621 & 30 \\
\hline 2018 & 1208 & 17 & 3717 & 53 & 2116 & 30 \\
\hline \multirow[t]{2}{*}{2017} & 1606 & 17 & 4798 & 52 & 2799 & 30 \\
\hline & \multicolumn{6}{|c|}{ IMC, persons } \\
\hline 2018 & 492 & 21 & 1362 & 59 & 455 & 20 \\
\hline \multirow[t]{2}{*}{2017} & 510 & 21 & 1448 & 60 & 454 & 19 \\
\hline & \multicolumn{6}{|c|}{ Kernel Holding S.A., thsd persons } \\
\hline 2019 & 2,3 & 17 & 7,6 & 57 & 3,5 & 26 \\
\hline 2018 & 2,6 & 17 & 7,6 & 51 & 4,8 & 32 \\
\hline 2017 & 2,8 & 17 & 8,6 & 53 & 4,7 & 30 \\
\hline
\end{tabular}

Source: ASTARTA, 2021; IMC, 2019; Kernel, 2021; MHP, 2020 
At MHP SE in 2019, more than 2,500 employees participated in distance learning programs offered by MHP Cornerstone's personnel management system. The average duration of distance learning was 12 hours 12 minutes per employee who participated in it.

Total corporate social responsibility budget of ASTARTA Holding N.V. for 2019 was 1.2 million EUR, including a total training cost of 0.2 million EUR. 4489 employees (which is $56 \%$ of the average number of employees) were trained in the following areas: professional trainings - 2430, labor protection - 976, product quality assurance -249 , environmental protection - 80 , prevention of discrimination and human rights violations - 66. The average number of training hours per employee in 2019 was 11.7 hours, including for: managers 13 hours; specialists - 11.1 hours; workers 11.2 hours.

The IMC integrated reporting discloses information on financial incentives for employees based on the results of their questionnaires. The answers to the sources of motivation as a percentage of respondents are as follows: possibility to earn money/salary level $-37.8 \%$; opportunity to learn/gain experience $37.3 \%$; positive atmosphere in the team $-25.6 \%$; high level of social protection $-25,1 \%$; I can realize myself as a professional $-23,6 \%$. According to the results of $2018,3901.9$ thsd was spent on nonfinancial incentives for IMC employees. The largest share (2026.4 thsd UAH, or 52\%) is directed to motivational trips abroad, about $22 \%$ to targeted help for employees and corporate events respectively 842 thsd UAH and 876.5 thsd UAH. A much smaller part (4\%, or 157 thsd UAH) is directed to the summer camp for the employees' children.

In 2018, the total number of IMC's employees who were trained was 705 people, which was more than twice the corresponding figure for 2017 (338 people). In 2017, the bulk of them (253 people, $74.9 \%$ ) accounted for production personnel, in 2018 - for non-production personnel (397 people, or 56.3\%). IMC spent about 2.5 million UAH on personnel training in 2018.
At Kernel Holding S.A., the duration of staff training in 2020 was 112,186 hours, which was $20 \%$ higher than in 2019 (92,000 hours). In the structure of skill set, hard skills account for $85 \%$, soft skills $-15 \%$. Learning formats provided for the share of study hours: $78 \%$ - full-time training, $22 \%$ distance learning. Training frequency was: $52 \%-$ annual/regular training, $41 \%$ - one-time training, $7 \%$ - modular development programs. Average training hours by profession: managers - 26.5; specialists - 15.7; workers- 4.5 . Average training hours by gender: male -10.1 , female -7.4 .

\section{Conclusions}

The components of integrated reporting of four agricultural corporations of Ukraine are summarized. Their similarity is determined by the substantive characteristics associated with the disclosure of information about the impact of the enterprise on the environment, social and economic impact, corporate governance, animal well-being. The differences are related to the form of presentation of information, the number of sections of integrated reporting.

The example of human capital has clearly shown that information about it is reflected in various sections of integrated reporting: "Social impact", "Social and inclusion", "Personnel", "People". The conceptual basis of human capital management and features of program in separate researched agrarian corporations are generalized.

The analysis of human capital as an object of integrated reporting of agricultural corporations on the indicators of the total number of staff, its permanent and seasonal part, gender composition, categories of employees, age, duration of training has been carried out. Disadvantages of disclosing information on human capital are the prevalence of quantitative indicators over qualitative ones, in particular, there is a lack of indicators of labor productivity, average wages compared to the industry level. The recommendation for staff motivation mechanisms is the use of corporate health insurance.

The purpose of further research is to substantiate proposals for the disclosure of information on intellectual capital in integrated reporting.

\section{References:}

Argento, D., Culasso, F., \& Truant, E. (2019). From Sustainability to Integrated Reporting: The Legitimizing Role of the CSR Manager. Organization \& Environment. Sage Journals, 32(4): 484-507. doi: https://doi.org/10.1177/1086026618769487 
ASTARTA Holding N. V. (2021). Sustainability Report - 2020. Available at: https://astartaholding.com/ files/uploads/3838c460ac05715b7e6f9573a9855c84.pdf (accessed 29 April 2021).

Havlová, K. (2015). What Integrated Reporting Changed: The Case Study of Early Adopters. Procedia Economics and Finance, 34: 231-237. doi: https://doi.org/10.1016/S2212-5671(15)01624-X

IMC (2019). Corporate Social Responsibility Report 2017|2018. Available at: https://imcagro.com.ua/ images/docs/Social_report/IMC_CSR\%20report\%202017-2018_EN.pdf (accessed 27 April 2021).

Ishchenko, Ya. (2019). Oblik vytrat ta vykhodu orhanichnoi silskohospodarskoi produktsii roslynnytstva [Accounting for costs and yield of organic agricultural crop products]. Institute of Accounting, Control and Analysis in the context of globalization. International scientific journal, 3-4: 26-36.

Kernel Holding, S. A. (2021). Sustainable development approach - 2020. Available at: https://www.kernel.ua/wp-content/uploads/2020/12/Kernel-Sustainability_Presentation_20201203.pdf (accessed 26 April 2021).

Kostyrko, R. O. (2014). Perspektyvy mizhnarodnoi intehrovanoi zvitnosti [Prospects of international integrated reporting]. Bulletin of the National University "Lviv Polytechnic". Management and entrepreneurship in Ukraine: stages of formation and problems of development, 794: 181-187.

MHP SE (2020). Non-financial Report Sustainable development - 2019. Available at: https://api.webtest.next.mhp.com.ua/images/512bd/51d31/2b37956bf68.pdf (accessed 28 April 2021).

Patrikats, L., \& Patsera, M. (2013). Vprovadzhennia MSFZ ta intehrovanoi zvitnosti spryiatymut yevropeiskii intehratsii Ukrainy [Implementation of IFRS and integrated reporting will contribute to Ukraine's European integration]. Bulletin of the National Bank of Ukraine, 10: 54-57.

Romolini, A., Fissi, S., \& Gori, E. (2017). Exploring Integrated Reporting Research: Results and Perspectives. International Journal of Accounting and Financial Reporting, 7(1): 32-59. doi: http://dx.doi.org/10.5296/ijafr.v7i1.10630

Sobchenko, A. M., \& Krukovska, O. V. (2015). Hroshovi potoky u systemi intehrovanoho bukhhalterskoho obliku ta finansovoi zvitnosti silskohospodarskykh pidpryiemstv [Cash flows in the system of integrated accounting and financial reporting of agricultural enterprises]. Science and economics, 3: 23-27.

Stovpova, A. S. (2019). Kontseptsiia intehrovanoi zvitnosti mizhnarodnykh kompanii u konteksti implementatsii zakonodavstva YeS [The concept of integrated reporting of international companies in the context of the implementation of EU legislation]. Scientific works of NDFI, 3: 114-125.

Vasylishyn, S. I. (2020). Metodychni zasady rozkryttia ekonomichnoi bezpeky v intehrovanii zvitnosti ahrarnykh pidpryiemstv [Methodical bases of disclosure of economic safety in the integrated reporting of the agrarian enterprises]. Bulletin of KhNAU. Series: Economic Sciences, 1: 65-78.

Yefymenko, T. I. (2014). Zaprovadzhennia intehrovanoi zvitnosti ta reformuvannia bukhhalterskoho obliku v umovakh yevrointehratsii [Introduction of integrated reporting and accounting reform in the context of European integration]. Finance of Ukraine, 10: 7-23. 